\title{
Meeting the quest for spatial efficiency: progress and prospects of extensive aquaculture within offshore wind farms
}

\author{
B. H. Buck · G. Krause • T. Michler-Cieluch • \\ M. Brenner · C. M. Buchholz · J. A. Busch · R. Fisch • \\ M. Geisen · O. Zielinski
}

Received: 11 April 2008 / Accepted: 18 April 2008 / Published online: 20 May 2008

(C) Springer-Verlag and AWI 2008

\begin{abstract}
Along the German North Sea coast, the observed high spatial competition of stakeholders has encouraged the idea of integrating open ocean aquaculture in conjunction with offshore wind farms beyond the 12 miles zone. The article provides an overview on the current state of transdisciplinary research on a potential implementation of such a multifunctional use concept on a showcase basis, covering
\end{abstract}

Communicated by H.-D. Franke.

B. H. Buck $(\bowtie) \cdot$ T. Michler-Cieluch $\cdot$ M. Brenner .

C. M. Buchholz · J. A. Busch · R. Fisch

Alfred Wegener Institute for Polar and Marine Research (AWI),

Am Handelshafen 12, 27550 Bremerhaven, Germany

e-mail: Bela.H.Buck@awi.de

B. H. Buck · M. Brenner · J. A. Busch · R. Fisch · M. Geisen ·

O. Zielinski

Institute for Marine Resources (IMARE),

Klußmannstrasse 1, 27570 Bremerhaven, Germany

B. H. Buck · O. Zielinski

Bremerhaven University of Applied Sciences,

An der Karlstadt 8, 27568 Bremerhaven, Germany

G. Krause

Center for Tropical Marine Ecology (ZMT),

Fahrenheitstrasse 6, 28359 Bremen, Germany

M. Brenner

Jacobs University Bremen gGmbH,

Campus Ring 1, 28759 Bremen, Germany

C. M. Buchholz

Biological Institute on Helgoland (BAH),

Alfred Wegener Institute for Polar and Marine Research,

27483 Helgoland, Germany

R. Fisch

University of Bremen, Bibliothekstraße 1,

28359 Bremen, Germany biological, technical, economic and social/policy aspects as well as private-public partnerships and the relevant institutional bodies. We show that the cultivation of seaweeds and blue mussels is biologically and technically feasible in a high-energy environment using modified cultivation strategies. The point of departure of our multi-use concept was that the solid groundings of wind turbines could serve as attachment points for the aquaculture installations and become the key to the successful commercial cultivation of any offshore aquatic organism. However, spaces in between the turbines are also attractive for farming projects, since public access is restricted and thus the cultivation site protected from outside influences. An economic analysis of different operation scenarios indicates that the market price and the annual settlement success of juvenile mussels are the main factors that determine the breakeven point. Social and policy science research reveals that the integration of relevant actors into the development of a multi-use concept for a wind farm-mariculture interaction is a complex and controversial issue. Combining knowledge and experience of wind farm planners as well as mussel fishermen and mariculturists within the framework of national and EU policies is probably the most important component for designing and developing an effective offshore co-management regime to limit the consumption of ocean space.

Keywords Offshore aquaculture - Offshore wind farms . Co-management $\cdot$ ICZM $\cdot$ Mussel cultivation $\cdot$ Seaweed cultivation

\section{Introduction}

The political recognition on a national as well as on EU level that the implementation of integrated coastal zone 
management (ICZM) is still fragmentary acted as incentive to investigate in more detail how this could be overcome (BMU 2006). In Germany, it generated a call of the Federal Ministry of Education and Research to the various federal states to develop projects that address ICZM on a regional level. In 2004, the programme Coastal Futures (Kannen 2004) tying up various administrative and scientific bodies and the public along the west coast of the State of SchleswigHolstein was granted funding. This programme focussed on two issues: (1) to develop the future of the coast as a living, working and recreational space for the local population, and (2) to consider the potential contribution of coastal resources to the sustainable development on the national and EU/global level, i.e. by providing regenerative energy through wind power. In order to sustain sufficient open space for future development, the idea of combining offshore wind power generation with other uses, such as aquaculture operations, emerged (Buck 2002). Marine aquaculture is a growing enterprise in Germany as well as in the whole of Europe, strongly motivated by the decline of fisheries production and the search for alternative income options for rural peripheral coastal regions.

In order to stimulate multifunctional use of marine space, it was decided to develop a project on a showcase basis, which deals not only with different scientific fields but also with private-public partnerships and the relevant institutional bodies. In the following, we provide an overview on the current state of research undertaken within this focus.

\section{Background}

"Fisheries have rarely been sustainable". This statement by Pauly et al. (2002) was based on the lack in sustainability, induced by a serial depletion of wild stocks worldwide because of improved technology, geographical expansion and exploitation of previously spurned species lower in the food web. In exchange, aquaculture was often discussed to bridge the gap between supply and demand or, in contrast, even to exacerbate this scenario.

Since the 1970s, aquaculture production has grown quite rapidly and is by now one of the fastest growing aquatic food production sectors in the world (FAO 2004). Besides the rapid development of this sector, the wide-ranging decline in fisheries yields has been enhanced by an increase in public demand for aquatic products. With an annual share of more than $15 \%$ of total animal protein supplies, the production of capture fisheries and aquaculture plays a significant role in global food security (FAO 2004). In 2004, approximately 160 million tonnes of aquatic organisms were produced worldwide (Fig. 1). From that amount, global aquaculture accounts for almost $37.7 \%$ of total edible

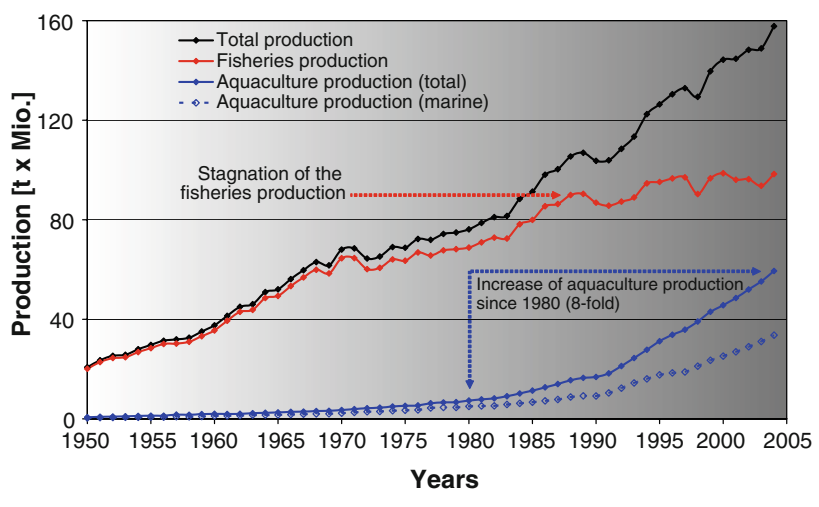

Fig. 1 Global production of aquatic organisms originating from fisheries and aquaculture within the last 55 years (data source FAO 2006, modified after Buck 2007b)

production, totalling about 60 million tonnes of aquatic organisms (FAO 2006). Today, a wide range of aquatic species is raised in various systems, onshore as well as in the ocean. According to the FAO (2004), approximately 300 different species, ranging from fish to shellfish, crustaceans and algae are produced in aquaculture systems. Most of these traditionally founded aquaculture enterprises are concentrated in well-protected and therefore favourable inshore water areas (Burbridge et al. 2001).

Even though over-reporting its aquaculture production (Rawski and Xiao 2001), the People's Republic of China contributed approximately $70 \%$ to the world's aquaculture production in 2004. It is nevertheless debatable, whether this production can compensate for the global deficiency in aquatic food. In addition, the intensive traditional aquaculture of carnivorous species does not automatically relieve pressure on ocean fisheries (Naylor et al. 2000). Salmon farming, e.g., requires large inputs of wild fish as fish oil and fish meal for the production of feed. On the other hand, the major increase in aquaculture production originates from herbivorous species and the production is anyway heavily skewed towards herbivores (Roth et al. 2002). Hence, the farming of non-carnivorous species that is not dependent on fishmeal-based feeds is considered a sustainable way of producing food.

On top of this debate, nowadays an increasing limitation of favourable coastal sites for the development of modern aquaculture is evident in countries such as Germany (Buck 2004). This spatial limitation is mainly caused by the lack of protected nearshore areas and by the fact that regulatory frameworks that assign specific areas for aquaculture operations in Germany and other countries bordering the North Sea are diverse and still emerging. This situation is in contrast to the production progress in developing countries, in which the installation of aquaculture systems benefits from the often weak enforcement of integrated coastal management schemes, which regulate equal access to the coastal 
resources (Davis and Bailey 1996; Adger and Luttrell 2000). Thus, the rise of aquaculture production has specifically taken place in developing countries, especially in Asia, which holds approximately $91.4 \%$ of the global production share (Rana 1997; Lee and Turk 1998; FAO 2006). In addition frequently in various cases, overlapping use of coastal habitats adds to the increasing pollution of coastal waters and gives rise to spatial conflicts, thus leaving little room for the expansion of modern coastal aquaculture systems. This problem has triggered the movement to offshore areas, where little spatial regulations have been established so far and clean water can be expected (Krause et al. 2003). There is an enormous economic potential for extensive marine aquaculture in offshore areas.

What is extensive marine aquaculture?

In contrast to intensive aquaculture operations, extensive aquaculture covers a line of production in a sustainable manner. Following the definition of the FAO $(1989,1997)$ aquaculture is the farming of aquatic organisms including fish, molluscs, crustaceans and aquatic plants with some sort of intervention in the rearing process to enhance production, such as regular stocking, feeding and protection from predators. Specifically, marine aquaculture, also called mariculture, concentrates on aquatic organisms cultivated in brackish or marine environments. If aquaculture operations are characterized by (1) a low degree of control (i.e. environmental control, nutrition, preditors, competitors and disease agents), (2) low initial costs, (3) low level technology, (4) low production efficiency and (5) high dependence on local climate and water quality (natural water bodies such as bays, ponds, embayments), it is defined as extensive marine aquaculture (Eleftheriou 1997). Finally, offshore aquaculture or open ocean aquaculture is defined as (1) being in a marine environment fully exposed to all kinds of oceanographic conditions (Ryan 2005), and (2) located at least eight nautical miles off the coast (Buck 2004), avoiding tremendous stakeholder conflicts in nearer coastal areas (Dahle et al. 1991). The procedures and applied techniques for the cultivation of organisms mainly depend on the species; their life cycle determines the phase of cultivation and the location for the grow-out, where market size is reached.

In the North Sea, only indigenous species can be considered for aquaculture to avoid the disruption of local flora and fauna in ecologically highly sensitive areas of the Wadden Sea. This limits the economic opportunities of aquaculture enterprises, since only a few indigenous candidates are regarded as high-value species (BLE 2003). Following a feasibility study by Buck (2002), only culture species with modest service needs can be considered as favourable candidates. In this study, the most suitable candidates identified for offshore extensive aquaculture were the sugar kelp (Laminaria saccharina), dulse (Palmaria palmata), the blue mussel (Mytilus edulis) and two oyster species, the Pacific oyster (Crassostrea gigas) and the European flat oyster (Ostrea edulis).

Mussels and seaweed are cultured mainly in extensive systems throughout the world (Hickman 1992; Critchley et al. 2006; Buck 2007a), the latter for historical and traditional reasons being mostly found in Asian countries. Worldwide, several techniques exist to cultivate mussels and seaweed either in co-culture or in single culture. Basically, both organisms are cultured in a suspended manner in the water column, floating or submerged. Today, the use of rafts, longlines and ring methods dominate (Fig. 2). The latter two were the main cultivation techniques used throughout our research studies in offshore areas of the German Bight (North Sea; Hickman 1992; Buck and Buchholz 2004; Buck 2007a).

\section{Offshore wind farms as a newcomer}

High and reasonably steady wind speeds occur regularly in offshore areas, making such areas prime candidates for renewable energy production by wind energy farms. In Germany, a major political incentive $e^{1}$ exists currently to install large offshore wind farms (Tiedemann 2003; BMU/ Stiftung Offshore Windenergie 2007). The promotion of wind power is mainly driven by the policy to reduce the dependence on conventional fossil energy resources as well as the need to reduce the environmentally harmful $\mathrm{CO}_{2}$ loads. Thus, the emerging branch of offshore wind farms appears as a new stakeholder on the list of users (GierloffEmden 2002; Dahlke 2002; Tiedemann 2003).

At present, 47 project applications for wind farms in the Economic Exclusive Zone (EEZ) of the German North Sea and in the Baltic Sea are in the planning process (BSH 2008) with the total number of wind turbines per farm ranging between 80 and 500 (Buck 2002). In November 2001, the Federal Maritime and Hydrographic Agency (BSH)

\footnotetext{
${ }^{1}$ Wind energy continues to be the world's most dynamically growing energy source. The first initiative towards an economy based on renewable energy resources in Germany was set by the governmental decision to gradually reduce the use of nuclear energy and to respond to the gradually diminishing fossil and nuclear energy reserves. Simultaneously, the output of $\mathrm{CO}_{2}$ to the atmosphere is reduced (Kyoto protocol). So far, this development has been successful to such an extent that around $7.2 \%$ of the energy needs in Germany are covered by this technology. At the end of 2007, Germany had an installed capacity of 22,247 MW, generated by 19,460 operating wind turbines (BWE 2008). Within Europe as the leading market for wind energy with over $57 \mathrm{GW}$, Germany thus accounted for $39 \%$ in terms of installed capacity and still remains the world's leader. However, with the North American market currently experiencing a strong growth, it is expected that the US will overtake Germany by the end of 2009 (GWEC 2007).
} 

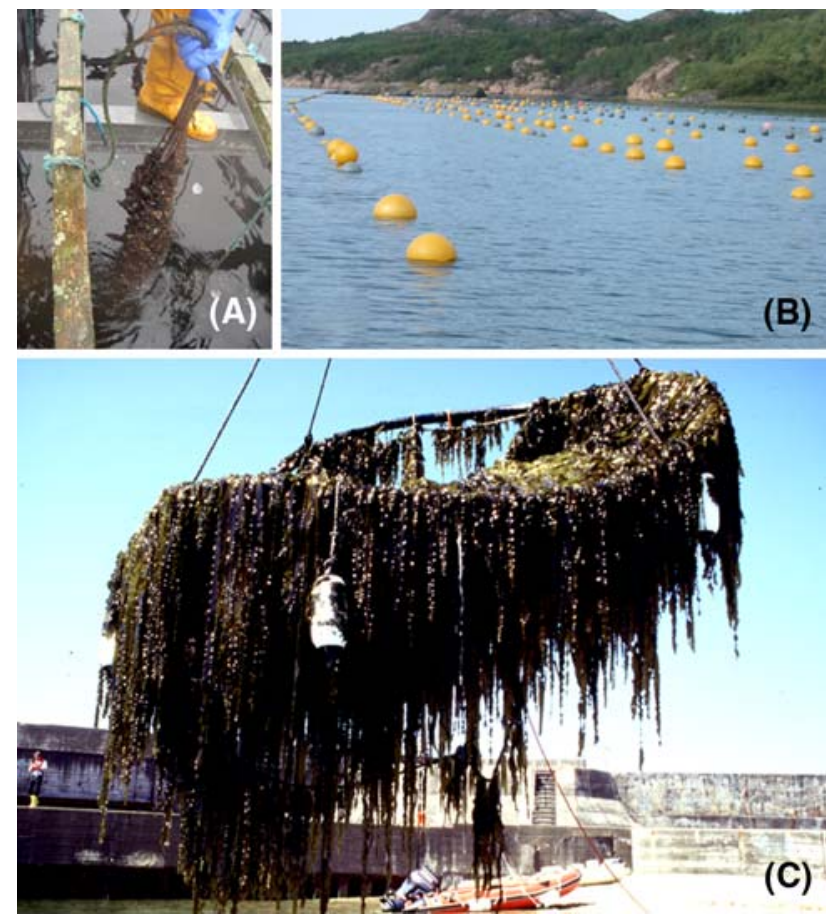

Fig. 2 Methods to cultivate mussels and seaweed in a suspended or floating design. a shows a raft system where mussel collectors are attached vertically from a wooden frame. b A horizontally installed longline floating on the surface. The mussel collectors are attached below the water surface vertically to the longline. $\mathbf{c}$ A floating ring system for the cultivation of seaweed at harvest time (Buck and Buchholz 2004)

granted the first approval for the installation of a pilot offshore wind farm: The Prokon Nord Company received the permit to install 12 wind turbines in the German EEZ of the North Sea, approximately $45 \mathrm{~km}$ north of the island of Borkum with the option of expanding the wind farm up to a total of 208 wind turbines by the year 2010. Since then, a total of 20 wind farm development projects have been approved in German waters, most of them planned seaward of the 12 nautical miles zone: 17 in the EEZ of the North Sea and 3 in the EEZ of the Baltic Sea (BSH 2008). Currently, only a test field of 12 wind turbines at the site of the licensed wind farm "Borkum West" is being constructed. Experience gained in this project should give developers practical knowledge in the construction and operation of offshore wind farms at depths and at distances from the shore that are beyond comparison to those anywhere in the world (BMU/Stiftung Offshore Windenergie 2007; Dena 2007).

In contrast to neighbouring European states, the prospect of moving wind energy developments offshore stagnates in Germany mainly due to a very complex licensing procedure and the high environmental restraints (BMU/Stiftung Offshore Windenergie 2007; BWE 2007). A further constraint lies in the spatial competition of offshore wind farms with other utilization of the marine waters in the German
Bight. Such conflicts result from shipping (trade or private), recreational activities, extraction or disposal of gravel, military missions, fisheries, aquaculture, cable and pipelines, nature reserves areas, and other marine and coastal protected areas (Wirtz et al. 2003; Buck et al. 2004; BSH 2007). However, despite the number of competing users within offshore regions being lower compared to coastal areas (Jentoft 2000), the quest for spatial efficiency remains to be a key incentive also for offshore developments in the future.

Moving offshore: the multi-use idea

The plans for the massive expansion of wind farms in offshore areas of the North Sea triggered the idea of a combination of wind turbines with installations of extensive shellfish and macroalgae aquaculture (Buck 2002; 2004). Offshore wind farms provide an appropriately sized area free of shipping traffic. At the same time the infrastructure for regular service support is readily available and hence such sites provide an ideal opportunity for devising and implementing a multiple-use concept (Buck et al. 2004; Michler-Cieluch 2008). However, in contrast to coastal inshore areas where beaches and their adjacent nearshore zones act as buffers to absorb wave energy, offshore regions are high-energy environments fully exposed to waves, weather and currents. Numerous studies have demonstrated that waves can reach remarkable heights in offshore areas (e.g. Führböter and Dette 1983; Becker et al. 1992). In this context, the solid foundation structure of wind turbines provides support for anchoring cultivation devices that can withstand the harsh weather conditions (Buck et al. 2006). Furthermore, offshore structures are well known for their artificial reef function, thus supporting biodiversity in ecosystems. In comparison to inshore areas, water quality, a major element in aquaculture operations, is regarded to be very good (Takayanagi 1998; BSH 2006). Finally, the multifunctional use of offshore areas reduces conflicts between stakeholders, if activities are concentrated and conjointly managed within so-called multiple-use marine areas. This, in turn, increases the amount of open ocean territory free of utilization by man. The above issues are considered as key incentives to move offshore with aquaculture operations.

Since an overall interest exists to move aquaculture activities to offshore locations, different suggestions for technical structures were proposed (see proceedings of various OOA-Conferences: e.g. Stickney 1998; Bridger and Costa-Pierce 2003). Major difficulties in the development of suitable techniques for open ocean (offshore) aquaculture are the harsh environmental conditions, which place an enormous stress on the materials used. It would be advantageous for Germany's offshore aquaculture development to plan for a combination of uses. While windmills use the 
wind above the surface to produce energy, their fixed pylons, commonly concrete fundaments (gravity foundation), metal jackets or tripods, offer a possibility to connect systems used in aquaculture. The combination of these two industries has to cope with the forces generated by the highenergy environment. Hence in designing such structures, the forces must be taken into consideration.

Scope of offshore aquaculture research activities in the German North Sea

Only a few scientific studies dealing with the prospects of offshore aquaculture were available prior to the beginning of our studies presented below and little was known about the biotechnological requirements, economic potential or the socio-economic influence on the general feasibility of offshore aquaculture. Very few long-term experiments under harsh hydrodynamic conditions exist (e.g. Langan and Horton 2003 for offshore mussel cultivation; Neushul and Harger 1985; Neushul et al. 1992 for offshore seaweed cultivation), but data on system and species performance are urgently needed to derive methodologies for the assessment of its environmental and economic viability. Therefore, the assessment of the potentials and constraints for sustainable aquaculture development in all marine habitats requires input from various scientific disciplines in order to direct this development towards a successful aquaculture undertaking. In particular, this holds true for offshore aquaculture, where little practical experience is available to date, although research in this area is evolving rapidly (e.g. Turner 2001; Pérez et al. 2003; Bridger and Costa-Pearce 2003; Dalton 2004; Naylor and Burke 2005).

The Coastal Futures Programme initiated an integrated assessment of theoretical and practical challenges of aquaculture operations in the North Sea in combination with offshore wind farms. Several studies were carried out, all of which contribute to specific aspects of such a combined utilization of offshore space.

In the following, we group the completed and ongoing projects (see Table 1) into the following key areas of research:

(a) Biological studies, in which the focus is placed on cultivation and subsequent performance characteristics of indigenous bivalve and seaweed species exposed to extensive offshore aquaculture farming conditions. Further, the health status and infestation rates with parasites, bacteria and viruses of candidates are determined to gain reliable predictions on where the highest growth rates and best product quality for consumers can be achieved. To evaluate the significance and comparability of the employed parameters, the area of investigation was extended along the Atlantic coast from southern
Portugal to northern Denmark. Further on, the closely related mediterranean mussel Mytilus galloprovincialis was included in the analysis to test the effectiveness of all the parameters in different species.

(b) Physical and technical studies, where the effects of the prevailing hydrodynamics on candidates and culture constructions are investigated at specific offshore sites within the national boundaries of the German North Sea. At the same time the technical requirements needed for farming structures in high energy environments and their possible combination with offshore wind farms are assessed. New system designs for offshore farming will be developed and prototypes (e.g. offshore ring, offshore collector) are in the test stage. In addition to offshore seaweed and mussel cultivation, a new technology for finfish mariculture of turbot and cod will be tested in the project AquaInno (Fisch and Buck 2006). A floating plant (pond-in-pond systems), combining "in pond raceways" (IPR) and "recirculation aquaculture systems" (RAS), will be designed for nearshore employment and developed further for use in more exposed habitats.

(c) Management and institutional studies, which focus on the analysis of potential management approaches to implement a multi-use concept of offshore areas, integrating various stakeholders and their respective views and knowledge systems. This endorses the examination of the prevailing case laws and regulative and management framework conditions as well as a suggestion of decisive offshore co-management strategies to support such activities.

(d) Economic studies, in which economic evaluation of such multi-use concepts in offshore locations is conducted taking into consideration market conditions as well as investment and operating costs.

The conceptual approach relied on the results of a theoretical feasibility study (Project No. 1 in Table 1), which was carried out prior to practical research in the field. The sequence of and relations between the different projects are displayed in Fig. 3.

All of the results contribute to the Coastal Futures programme and support the quest to find innovative new approaches for sustainable use and alternative livelihoods of coastal populations.

\section{Detailed results of the projects}

Over the last decades, substantial insight has been gained on the terms and conditions active in the offshore environment. However, these data are only partly useful for the selection of offshore aquaculture sites, because they have 


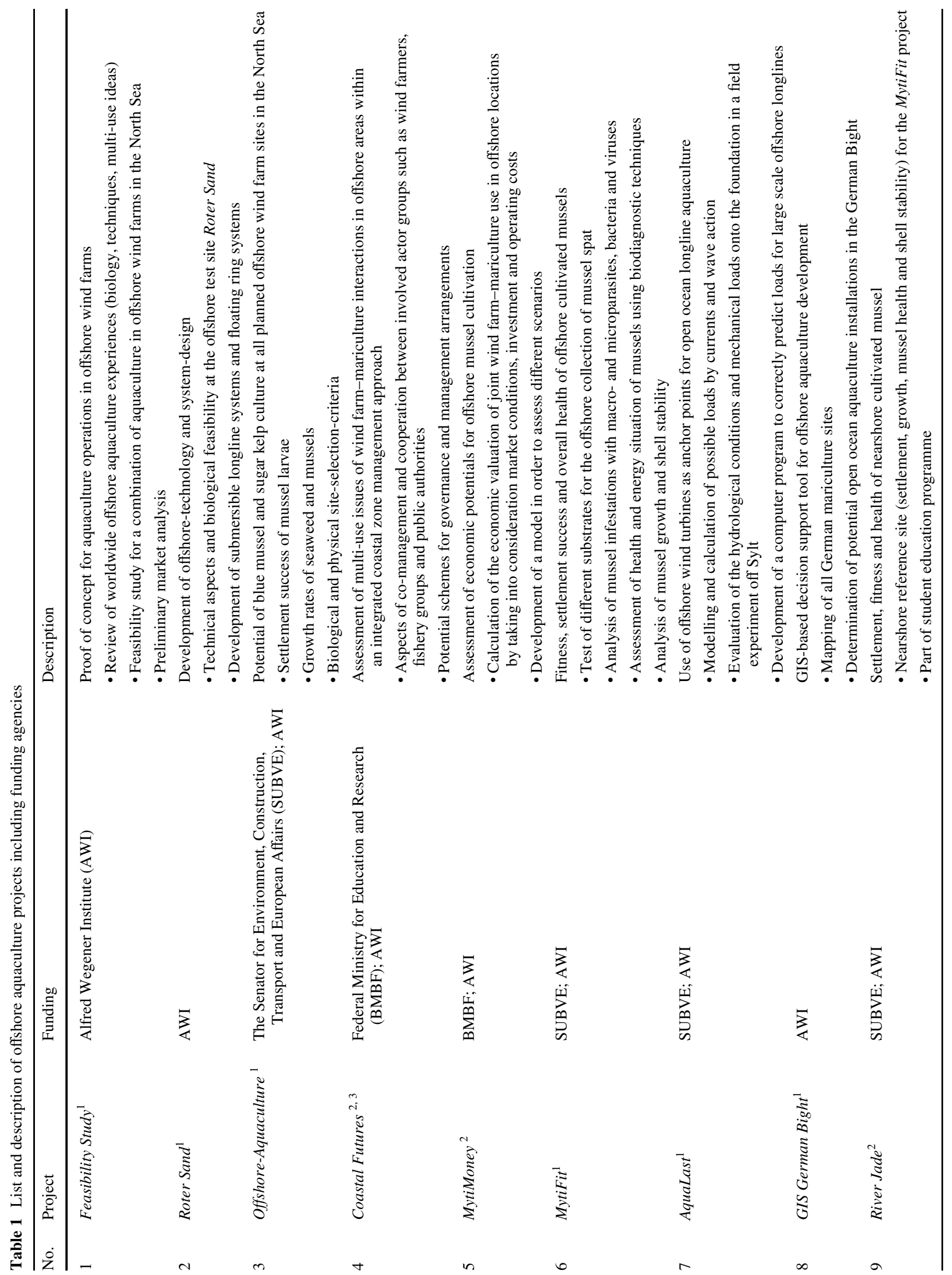


been gathered primarily for other user needs and thus lack the essential specificity to address the biological and cultivable potential of these sites. Prior to a multifunctional development comprising mariculture activities, it is therefore necessary to determine the appropriate biological, technological and management requirements as well as the performance characteristics that would allow the employment of favourable and cost-effective methodologies. To meet this end, special focus was placed on the combination of extensive offshore shellfish and seaweed farming at exposed sites within the proposed offshore wind farm boundaries.

Due to the wide spectrum, which is covered in the nine projects specified above, the outcomes are manifold. In the following, we present the various project results according to their contributions towards the main research topics involved.

\section{Biological studies}

The theoretical Feasibility Study Project (No. 1) was aimed to ascertain the biological, technical and economic feasibility of an offshore marine aquaculture structure with respect to the cultivation of marine organisms within wind farm sites in the German North Sea. One result was that to date in terms of commercial marine aquaculture Germany had little knowledge and background on offshore aquaculture compared to many other coastal countries throughout the world. Nevertheless, a synthesis of a selection of parameters (e.g. geo-physical and biological parameters) allowed the identification of suitable candidates for commercial offshore aquaculture. These candidates include blue mussels (Mytilus edulis) and oysters (Ostrea edulis, Crassostrea gigas), which could be maintained extensively in the offshore region. Moreover, labour requirement for these candidates as well as for seaweeds, such as the sugar kelp (Laminaria saccharina) and dulse (Palmaria palmata), is supposed to be low.

In the Offshore Aquaculture Project (No. 3), the biological feasibility of cultivating mussels, oysters and kelp within offshore wind farm sites was investigated. The growth of these species was excellent in offshore environments, but differed depending on exposure sites, system designs, installation mode, and season. Settlement of young mussels on artificial collector substrates decreased with increasing distance from the shore (Walter et al. 2008). However, this did not limit the economic potential, if the thinning procedure was omitted following a "One-StepCultivation" concept (Buck 2004). Further, mussels were free of parasites at offshore locations due to dilution effects and the interrupted reproduction cycles of some macroparasites (Buck et al. 2005). Hydrodynamic forces could support length increase of seaweed blades when transferring 


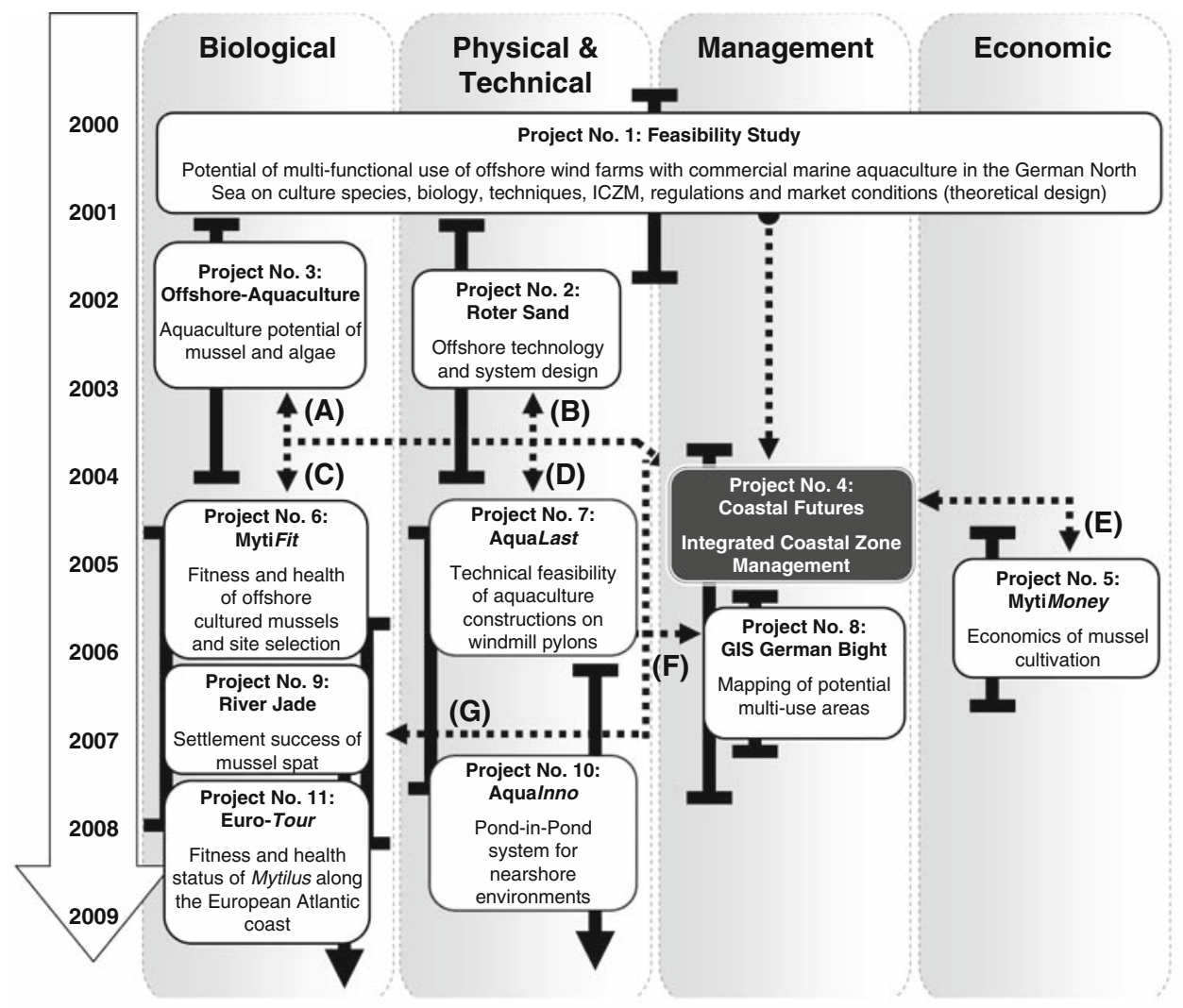

Fig. 3 Chronological order of conducted and ongoing research projects dealing with the combination of offshore wind farming and open ocean aquaculture. Project No. 1, the feasibility study, constituted the basis for all subsequent research. The Coastal Futures Project acts as a key node project to which the other projects either have contributed or by which they have been stimulated because of its transdisciplinary approach. It is visible that: $(A)$ calls the wind farm developers' attention to offshore aquaculture; $(B)$ and $(C)$ include authorities and fisher-

young sporophytes to sea. These algae will adapt to the occurring loads and develop strong holdfasts, preventing detachment of the entire plant (Buck and Buchholz 2005).

After the principal feasibility of offshore cultivation of algae and mussels was proven by the outcome of the Offshore Aquaculture Project, two further ongoing projects, MytiFit and River Jade (No. 6 and No. 9), were started in 2005 to elucidate more details regarding cultivation techniques. Additionally, the overall health status of mussels cultured under different conditions and the impact on economic aspects was investigated (Brenner et al. 2007). Specific aims of the projects were the development of suitable offshore spat collecting techniques, detailed knowledge about parasites (macro and micro), bacteria and virus infestations at different sites, implementation of biodiagnostic techniques for the health analysis of cultured mussels, and collection of all relevant data (e.g. shell stability and attachment strength of mussels), for the further processing of mussels as a product for human consumption. Modified and improved techniques for offshore farming withstand the men into the planning process for site selection criteria of appropriate aquaculture sites; $(D)$ involves offshore engineers and wind farm developers/operators into the technical part of an offshore aquaculture enterprise; $(E)$ introduces (mussel) fishermen to the co-management idea and appraises the economics of mussel cultivation; $(F)$ supplies authorities with maps and tools to limit regional stakeholder conflicts, and $(G)$ establishing an inshore reference station to support the data collected offshore

high-energy environment of the North Sea, but will certainly cause higher investment costs. Therefore, site-selecting criteria for a culture area should be clearly identified to assess economic risks. Important for the cultivation success is the water quality. The analysis of the cultured organisms with biodiagnostic tools provides detailed insights into the water conditions the animals live in. By this approach, reliable predictions are possible as to which locations grant highest growth rates and best product quality for consumers. Preliminary results attest offshore areas satisfying settlement success and excellent growth rates (Manefeld 2006) and low infestations with macroparasites (Voss 2006), microparasites, bacteria and toxins (Brenner et al. 2007).

First results in the Euro-Tour Project (No. 11) show that mussels originating from offshore habitats have a better health status regarding the infestation with macro- and microparasites (Buck and Brenner, unpublished data), while macroparasites were found in mussels from nearshore areas in the Wadden Sea (the Netherlands, Germany, Denmark), whereas microparasites were absent. 
Physical and technical studies

The first technically oriented studies were conducted in the project Roter Sand (No. 2). The results of this study allowed the identification of two offshore aquaculture systems that were best suited for offshore operations from a biological point of view. Depending on the impacting hydrodynamic properties, different technical setups were regarded as favourable. The first one is a floating and submergible ring system for the cultivation of seaweed. It withstands rough weather conditions and allows easy handling (Buck and Buchholz 2004). The second system is a submerged longline design for blue mussel culture (Buck 2007a). The longline should be installed $5 \mathrm{~m}$ below the water surface and be connected to foundations of offshore windmills. For the longline, polypropylene proved to be an appropriate material. The system design is made of various connected segments allowing an easy harvest and replacement of the parts of the construction. However, more technical engineering research is required to find the most costeffective mode of construction and the best choice of materials (e.g. little corrosion, longevity in spite of mechanical stress) so that easy handling can be guaranteed under relatively harsh weather conditions (cf. construction, deployment, retrieval, service, repairs).

The technical realization and the implications of aquaculture technical requirements on design and construction of the grounding construction of offshore wind turbines were considered in the AquaLast Project (No. 7, Buck et al. 2006).

So far, modelling and experimental validation of a submerged $50 \mathrm{~m}$ longline aquaculture construction mounted between two steel piles, 17 nautical miles off the coast, showed significant forces of up to $90 \mathrm{kN}$ (equivalent to 9 tons) induced by waves of up to $1.8 \mathrm{~m}$ significant wave height and tidal currents of up to $1.0 \mathrm{~m} / \mathrm{s}$ (Zielinski et al. 2006). Given the high-energy environment in the North Sea and the non-linear relationship between water movement and its resulting forces, even higher mechanical loads are to be expected within the life cycle of such an arrangement.

Future work will (a) continue to monitor the experimental setup under different environmental conditions, (b) improve model parameters, such as drag coefficients by means of laboratory experiments, and (c) scale up the $50 \mathrm{~m}$ longline experiment as part of a simulation to full length using realistic foundations, such as monopiles and tripods. The resulting mechanical loads will then be considered as boundary conditions for the construction of wind farm foundations and additional demands in material, risk calculations and safety measures will be identified and economically quantified. The latter aspect will be a substantial factor for the successful integration of wind farmers in an offshore co-management scheme.
Furthermore, commercially produced nearshore collectors and self-designed collectors made of PP-fleece, PE or natural strand, like coconut, were tested under harsh offshore conditions. First results show that postlarvae and settled juvenile mussels prefer different materials and different material surfaces. With these results, a new collector for the use in high-energy environments can be developed.

Finally, the new pond-in-pond system in the AquaInnoProject (No. 10, Fisch and Buck 2006) with an internal wastewater treatment for the use in sheltered and nearshore areas has the potential to lower environmental impact of fish culture facilities, such as net pens or cages, where pollution from faeces, medicine and food pellets is mainly "solved" by dilution. It is able to reduce the nutrient load not only from the fish holding unit, but also from the surrounding water column in which the entire system is floating. The system will be improved to fulfil new guidelines set by the EU.

\section{Management and institutional studies}

In the Coastal Futures Project (No. 4) research on stakeholders' perspectives towards a potential wind farm-mariculture interaction reveals that integrating the perceptions and demands of the various resource users into the development of a multiple-use concept is a complex and controversial issue (Michler-Cieluch and Krause 2008). Different values need to be harmonized. So far, disagreements on the distribution of entitlements to benefits and profits between the different stakeholders can be observed (Table 2).

Our ongoing multidisciplinary social science research implies that the effective input of wind farmers and future mariculture operators such as mussel harvesters into a negotiation and bargaining process is the most essential component for the formation of an effective wind farmmariculture co-management regime. Both acting groups know best what kind of tasks and activities have to be performed offshore for their purposes and what kind of rules would have to be applied for jointly using an ocean territory. Top-down induced management schemes by, e.g., the national government hold a high potential for failure. Moreover, involving the relevant actors improves the social acceptability of innovating concepts and their applicability (Heinelt 2002). Consequently, we argue that for developing and implementing a wind farm-mariculture multiple-use concept, co-management such as that described by Carlsson and Berkes (2005) should ideally "be carried out with the participation of different actors that typically try to find ways to learn from their actions and adapt the behaviour to the consequences of their own and other's actions" (p. 67). This must be supported by the relevant authorities at all levels and must find its way into the legislative framework at the EU and national level. 
If we consider co-management to be a network activity between private actors, such as wind farmers or mariculture operators/fishermen and public authorities, one of its basic characteristics is the fact that a third party can coordinate the activities of formally separated parties (Carlsson and Berkes 2005). Since ways and means have to be developed that balance the respective interests of dominant and politically supported wind farming participants and small-scale entrepreneurial harvesters, this model can also be suggested for a prospective wind farm-mariculture interrelation. Therefore, the key question has to be resolved on how institutional arrangements could act as "boundary organizations" (see Cash and Moser 2000) in the prospect of an offshore co-management process between wind farmers, future mariculture operators and governmental agencies. However, in order to define the functional structure of such a co-management regime in detail, reliable outcomes on economic and technical integration prospects of a joint wind farm-mariculture venture have to be produced. The latter is a major research demand, which was voiced by most of the interview partners so far (Michler-Cieluch and Krause 2008).

The GIS German Bight Project (No. 8) demonstrates that there are sites in the German Bight appropriate for open ocean aquaculture installations despite plenty of stakeholder conflicts. All test areas are situated near planned or approved offshore wind farms at places with adequate water depth, still not too far from the coast. Comanagement arrangements comprising offshore wind farms and aquaculture allow for installing the latter within or in close vicinity to wind farm territory. This is due to the fact that the use of designated wind farm areas is restricted to other stakeholders such as fisheries. In addition, the planned wind farms offer enough room for large aquaculture installations (Koch 2006).
Economic studies

The Feasibility Study Project (No. 1) gave a general overview on market prices, market demands, classification of candidate species as high value products and the cost of some infrastructure. The study looked into the possible market value of offshore aquaculture products in comparison to the performance of existing conventionally operated farms in coastal waters. Main focus was placed on existing experience within the European community. A result was that a strong market exists for the suggested mussels and oysters as well as for brown and red algae. This market is likely to expand in the near future. Red algae can be directly sold to the consumer as a healthy "green and clean" bio-food or used in industry for various purposes (e.g. emulsifiers, ingredients for food, medicine). The feasibility study rounds up with a final evaluation of all factors, which are critical for the development of a commercial offshore aquaculture in combination with the planned wind farms in the North Sea region.

However, the MytiMoney Project (No. 5) principally highlights specific economic criteria needed for mussel farming at a site within an offshore wind farm in the German Bight. The economic analysis of the combined wind farm-mariculture use, focussing on seed mussel production, demonstrates that the service life of infrastructure as well as the mussel yield obtained per meter longline are crucial factors determining profitability (Fig. 4). In contrast, shipping costs and the idea of developing an offshore servicing vessel that can jointly be used for wind farm and mariculture operations and maintenance (Buck et al. 2004) does not seem to have a strong influence on general cost reduction patterns. Finally, a full economic analysis of different operation scenarios (best case-worst case) indicated that the market price and the annual settlement

Table 2 Pros and cons expressed by representatives of different stakeholder groups towards suggested "wind farm-mariculture integration" (modified after Michler and Buck 2007; Michler-Cieluch and Kodeih (2008)

\begin{tabular}{|c|c|}
\hline Pros & Cons \\
\hline $\begin{array}{l}\text { Combination would increase acceptance of offshore } \\
\text { wind farms among population (administration) }\end{array}$ & $\begin{array}{l}\text { Uncertain profitability due to monumental technical } \\
\text { requirements for operating mussel and algae cultures } \\
\text { in the open sea (administration) }\end{array}$ \\
\hline Additional societal benefit (policy) & Economic feasibility very questionable (fishery) \\
\hline $\begin{array}{l}\text { Good innovative idea, though many open questions } \\
\text { have to be answered in advance (wind energy) }\end{array}$ & $\begin{array}{l}\text { Offshore wind farms are a source of danger for shipping; } \\
\text { danger of oil spills (tourism) }\end{array}$ \\
\hline $\begin{array}{l}\text { Multi-use of ocean territory reduces claiming } \\
\text { of additional areas (tourism) }\end{array}$ & $\begin{array}{l}\text { Lack of in-depth information on impacts; not imaginable } \\
\text { at present (policy) }\end{array}$ \\
\hline Additional jobs in the rural region likely (economy) & Lack of "neutral" information (fishery) \\
\hline $\begin{array}{l}\text { Opens up potentials for research and economic/financial } \\
\text { benefit; possibility for international image (research) }\end{array}$ & $\begin{array}{l}\text { Exaggerated synergetic effects should not be interpreted; } \\
\text { cultivation of shellfish is not part of a wind farm (economy) }\end{array}$ \\
\hline Initiation of a co-management scheme for the EEZ (research) & $\begin{array}{l}\text { The mariculture concept needs to see for itself. Otherwise it does } \\
\text { not convince in combination with offshore wind farms (administration) }\end{array}$ \\
\hline Interesting with regard to local gastronomy (tourism) & Loss of traditional fishery activities, e.g. trawl fishery (fishery) \\
\hline
\end{tabular}


Fig. 4 Factors influencing cost effectiveness of offshore seed mussel production within a wind farm territory in the North Sea

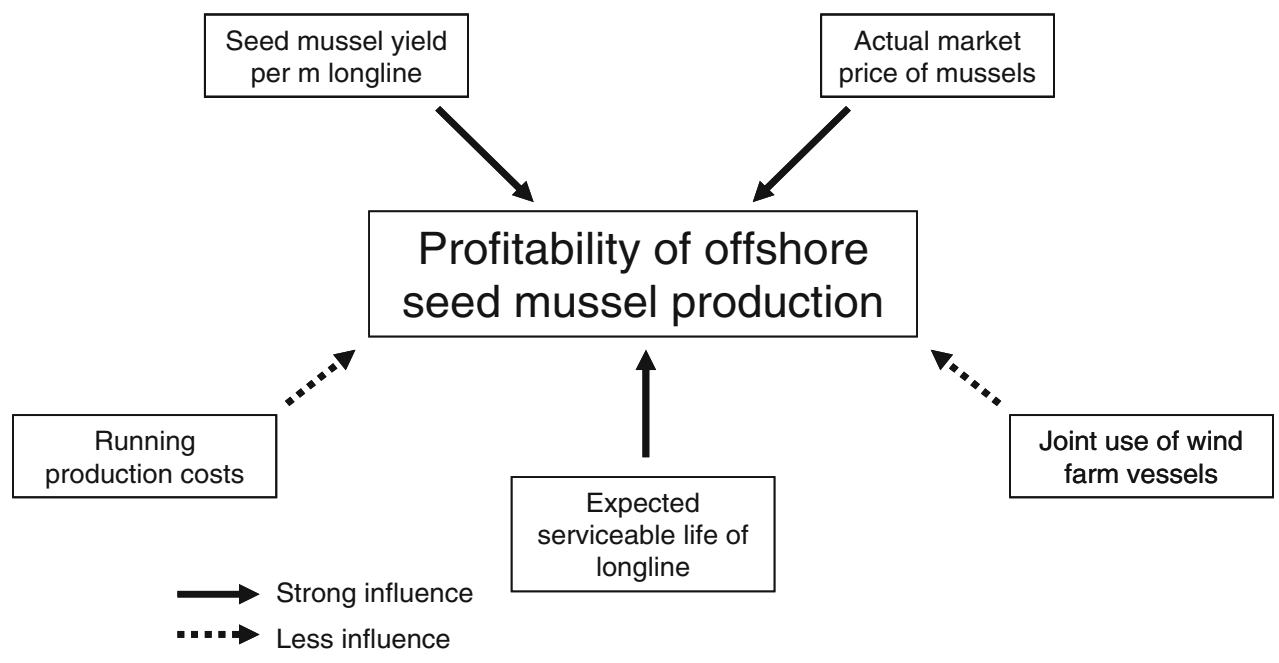

success of juvenile mussels were the main factors that determined the breakeven point.

Despite of these studies, the economics of a joint wind farm-mariculture utilization scheme still remain to be evaluated in detail. First results suggest concentrating on how to reduce investment costs for longlines used per culturing plot at offshore locations. This includes a more detailed analysis of the general start-up costs. Moreover, the prospect of cultivating mussels for direct consumption has to be considered in the future. The idea of having two production cycles in a single year is not possible due to the main spat fall event of blue mussels being between April and May (Pulfrich 1997).

\section{Conclusion and outlook}

By setting higher value on an inclusion of stakeholder knowledge and opinion, the initiation of the Coastal Futures Project (No. 4) resulted in a stronger focus on the practicability of multifunctional use of offshore areas. It can be shown that such innovative new concepts are highly complex and interdependent. First results indicate that secure technical and economic feasibility appears to be a basic prerequisite to assure that both, offshore wind farm operators and aquaculturists will support the multi-use concept, especially as far as the management of joint activities is concerned.

This suggests that as soon as technical and economic aspects are evaluated in more detail, it is important to initialize a comprehensive communication program to provide information to the key public and private actor groups (stakeholders). This in turn will increase their knowledge of the overall feasibility of combining different offshore uses and contribute to adding a joint wind farm-mariculture venture to their future portfolio.
Detailed data are needed to calculate the economic potentials and risks of a co-used wind farm area for the production of seafood. Apart from the principal feasibility of an area as an aquaculture site, growth rates and product quality must be predictable. First results on blue mussels from test areas offshore show that highest product quality can be expected from testing areas offshore. A proven product quality ensures higher market prizes, should compensate for higher investment costs for the culture systems and help to install a functioning offshore aquaculture system in the German Bight.

\section{References}

Adger WN, Luttrell C (2000) Property rights and the utilisation of wetlands. Ecol Econ 35:75-89

Becker G, Dick S, Dippner J (1992) Hydrography of the German Bight. Mar Ecol Prog Ser 91:9-18

BLE (2003) Der Markt für Fischereierzeugnisse in der Bundesrepublik Deutschland im Jahre 2003. Bericht über die Versorgung der Bundesrepublik Deutschland mit Fischereiprodukten aus Eigenproduktion und Importen sowie die Exportsituation. Bundesanstalt für Landwirtschaft und Ernährung, Referat -521/ Fischwirtschaft 7-10

BMU (2006) Integriertes Küstenzonenmanagement in Deutschland (IKZM). Nationale Strategie mit Bestandsaufnahme nach der EUEmpfehlung 2002/413/EG. Bundesregierung für Umwelt, Naturschutz und Reaktorsicherheit (Federal Ministry for the Environment, Nature Conservation and Nuclear Safety)

BMU/Stiftung Offshore Windenergie (2007) Offshore wind power deployment in Germany. Federal Ministry for the Environment, Nature Conservation and Nuclear Safety (eds)

Brenner M, Buck BH, Koehler A (2007) New concept combines offshore wind farms, mussel cultivation. Global Aquac Advocate 10:79-81

Bridger CJ, Costa-Pierce BA (2003) Open ocean aquaculture: from research to commercial reality. The World Aquaculture Society, Baton Rouge

BSH (2006) MURSYS-marine environment reporting system information from the North Sea and Baltic Sea. Bundesamt für Seeschiffahrt und Hydrographie (BSH), Hamburg 
BSH (2007) Bundesamt für Seeschifffahrt und Hydrographie - BSH (Federal Maritime and Hydrographic Agency), CONTIS-Geodata. Hamburg/Rostock (Germany). http://www.bsh.de. Accessed February 2007

BSH (2008) Wind farms. Bundesamt für Seeschifffahrt und Hydrographie (Federal Maritime and Hydrographic Agency). Hamburg/ Rostock, Germany. http://www.bsh.de. Accessed March 2008

Buck BH (2002) Open ocean aquaculture und offshore-windparks: Eine Machbarkeitsstudie über die multifunktionale Nutzung von Offshore-Windparks und Offshore-Marikultur im Raum Nordsee. Reports on Polar and marine research. Alfred Wegener Institute for Polar and Marine Research, Bremerhaven, pp 412-252

Buck BH (2004) Farming in a high energy environment: potentials and constraints of sustainable offshore aquaculture in the German Bight (North Sea). Dissertation, University of Bremen, Germany

Buck BH (2007a) Experimental trials on the feasibility of offshore seed production of the mussels Mytilus edulis in the German Bight: installation, technical requirements and environmental conditions. Helgol Mar Res 61:87-101

Buck BH (2007b) Marikultur als Co-Nutzung in Offshore-Windparks: Status Quo, Probleme und Perspektiven, Meeresumwelt-Symposium 2006 : 16. Symposium, 13. bis 14. Juni 2006, CCH - Congress Center Hamburg / Bundesamt für Seeschifffahrt und Hydrographie in Zusammenarbeit mit dem Bundesumweltamt im Auftrag des Bundesministeriums für Umwelt, Naturschutz und Reaktorsicherheit, pp 167-179

Buck BH, Buchholz CM (2004) The offshore-ring: a new system design for the open ocean aquaculture of macroalgae. J Appl Phycol 16:355-368

Buck BH, Buchholz CM (2005) Response of offshore cultivated Laminaria saccharina to hydrodynamic forcing in the North Sea. Aquaculture 250:674-691

Buck BH, Krause G, Rosenthal H (2004) Multifunctional use, environmental regulations and the prospect of offshore co-management: potential for and constraints to extensive open ocean aquaculture development within wind farms in Germany. Ocean Coast Manage 47:95-122

Buck BH, Thieltges D, Walter U, Nehls G, Rosenthal H (2005) Inshore-offshore comparison of parasite infestation in Mytilus edulis: implications for open ocean aquaculture. J Appl Ichthyol 21:107-113

Buck BH, Berg-Pollack A, Assheuer J, Zielinski O, Kassen D (2006) Technical realization of extensive aquaculture constructions in offshore wind farms: consideration of the mechanical loads. In: Proceedings of the 25th international conference on offshore mechanics and Arctic engineering, OMAE 2006: presented at the 25th International conference on offshore mechanics and Arctic engineering, 4-9 June 2006, Hamburg, Germany/American Society of Mechanical Engineers, pp 1-7

Burbridge P, Hendrick V, Roth E, Rosenthal H (2001) Social and economic policy issues relevant to marine aquaculture. J Appl Ichthyol 17:194-206

BWE (2007) Offshore Windenergie. BWE Hintergrundpapiere. Bundesverband WindEnergie. http://www.wind-energie.de/no_cache/ de/presse-service/hintergrundpapiere. Accessed February 2007

BWE (2008) Datenblatt 2007: Datenblatt Windenergie 2007. Bundesverband WindEnergie. http://www.wind-energie.de/de/statistiken/datenblatt-2005. Accessed March 2008

Carlsson L, Berkes F (2005) Co-management: concepts and methodological implications. J Environ Manage 75:65-76

Cash DW, Moser SC (2000) Linking global and local scales: designing dynamic assessment and management processes. Global Environ Change 10:109-120

Critchley AT, Ohno M, Largo DB (2006) World seaweed resources. An authoritative reference system. ETI BioInformatics. DVDROM
Dahle LA, DePauw N, Joyce J (1991) Offshore aquaculture technology-possibilities and limitations. Aquac Environ 14:83-84

Dahlke V (2002) Genehmigungsverfahren von Offshore-Windenergieanlagen nach der Seeanlagenverordnung. Natur und Recht 24:472-479

Dalton R (2004) Fishing for trouble. Nature 431:502-504

Davis A, Bailey C (1996) Common in custom, uncommon in advantage: common property, local elites, and alternative approaches to fisheries management. Soc Nat Resour 9:251-265

Dena (2007) Renewable energies: Germany's first test field for offshore wind energy. Dena fact sheet. German Energy Agency, Berlin

Eleftheriou M (1997) Aqualex: a glossary of aquaculture terms. WileyPraxis series in aquaculture and fisheries, Aqualex Multimedia Consortium Ltd

FAO (1997) Aquaculture development. Technical guidelines for responsible fisheries. Food and Agriculture Organisation of the United Nations, Rome, pp 5-40

FAO (2004) The state of world fisheries and aquaculture-2004 (SOFIA). Fisheries Department. Food and Agriculture Organisation of the United Nations, Rome, Italy

FAO (2006) Fishery information, data and statistics unit. Aquaculture production: values 1984-2004. FISHSTAT Plus-universal software for fishery statistical time series. Food and Agriculture Organization of the United Nations, Rome, Italy

FAO/FIDI (1989) Aquaculture production (1984-1986) Food and Agriculture Organisation of the United Nations. Rome Fisheries Circular. 815:106

Fisch R, Buck BH (2006) Neues Aquakultursystem für das Meer made in Germany. Fischerblatt 12:13-16

Führböter A, Dette HH (1983) Wasserstände, Wind und Seegang im Seegebiet um Helgoland in den Jahren von 1969 bis 1983. Leichtweiß-Institut für Wasserbau der TU Braunschweig, Bericht Nr. 577

Gierloff-Emden HGR (2002) Wandel der Umwelt der See- und Küstenlandschaft der Nordsee durch Nutzung von Windenergie. Mitteilungen der Österreichischen Geographischen Gesellschaft 144:219-226

GWEC (2007) Continuing boom in wind energy-20 GW of new capacity in 2007. Press release 15/02 200. Global Wind Energy Council. http://www.gwec.net. Accessed March 2008

Heinelt H (2002) Achieving sustainable and innovative policies through participatory governance in a multi-level context. In: Heinelt H, Getimis P, Kafkalas G, Smith R, Swyngedouw E, Opladen (eds) Particpatory governance in multi-level context. Leske + Budrich, pp 17-32

Hickman RW (1992) Mussel Cultivation. In: Gosling E (ed) The mussel Mytilus: ecology, physiology, genetics and culture. Development in aquaculture and fisheries science No. 25. Elsevier, Amsterdam, pp 465-510

Jentoft S (2000) Co-managing the coastal zone: is the task too complex? Ocean Coast Manage 43:527-535

Kannen A (2004) Holistic systems analysis for ICZM: the Coastal Futures approach. In: Schernewski G, Dolch T (eds) Geographie der Meere und Küsten. Coastline reports, vol 1, pp 171-181

Koch A (2006) Marine Aquakulturen im Nordseeraum. Status, Probleme und Potentiale unter besonderer Berücksichtigung der Deutschen Bucht. Diploma Thesis, University of Hanover, Germany

Krause G, Buck BH, Rosenthal H (2003) Multifunctional use and environmental regulations: potentials in the offshore aquaculture development in Germany. Proceedings of the multidisciplinary scientific conference on sustainable coastal zone management "Rights and duties in the coastal zone", 12-14 June 2003, Stockholm, Sweden

Langan R, Horton F (2003) Design, operation and economics of submerged longline mussel culture in the open ocean. Bull Aquac Assoc Can 103:11-20 
Lee PG, Turk PE (1998) Overview of a modern, shore-based hatchery for offshore mariculture support. In: Stickney RR (ed) Joining forces with industry - open ocean aquaculture. Proceedings of the third annual international conference, May 10-15, Corpus Christi, Texas. Corpus Christi, Texas Sea Grant College Program, pp 87102

Manefeld T (2006) Ansiedlungspotential von Miesmuschellarven (Mytilus edulis) an verschiedenen Substraten freihängender Brutkollektoren. Thesis, University of Applied Sciences Bremerhaven, Germany

Michler T, Buck BH (2007) Multi-purpose marine areas: integrating mariculture in offshore wind farms. Proceedings of the 2nd international conference on coastal conservation and management in the Atlantic and Mediterranean (ICCCM '07), 22-26 March, Hammamet, Tunisia, pp 107-110

Michler-Cieluch T, Kodeih S (2008) Mussel and seaweed cultivation in offshore wind farms: an opinion survey. Coast Manage (in press)

Michler-Cieluch T, Krause G (2008) Perceived concerns and possible management strategies for governing 'wind farm-mariculture integration'. Mar Policy. doi:10.1016/j.marpol.2008.02.008

Naylor R, Burke M (2005) Aquaculture and ocean resources: raising tigers of the sea. Annu Rev Env Resour 30:185-218

Naylor RL, Goldburg RJ, Primavera JH, Kautsky N, Beveridge MCM, Clay J, Folke C, Lubchenco J, Mooney H, Troell M (2000) Effect of aquaculture on world fish supplies. Nature 405:1017-1024

Neushul M, Harger BWW (1985) Studies of biomass yield from a near-shore macroalgal test farm. J Solar Energy Eng 107:93-96

Neushul M, Benson J, Harger BWW, Charters AC (1992) Macroalgal farming in the sea: water motion and nitrate uptake. J Appl Phycol 4:255-265

Pauly D, Christensen V, Guénette S, Pitcher TJ, Sumaila RU, Walters CJ, Watson R, Zeller D (2002) Towards sustainability in world fisheries. Nature 418:689-695

Pérez OM, Telfer TC, Ross LG (2003) On the calculation of wave climate for offshore cage culture site selection: a case study in Tenerife (Canary Islands). Aquacult Eng 29:1-21

Pulfrich A (1997) Seasonal variation in the occurrence of planktic bivalve larvae in the Schleswig-Holstein Wadden Sea. Helgol Wiss Meer 51:23-39

Rana KJ (1997) Aquatic environments and use of species subgroups. In: Review of the state of world aquaculture. FAO Fisheries Circular FIRI/C886 (Rev. 1). Food and Agriculture Organisation (FAO), Rome, Italy, pp 7-16

Rawski TG, Xiao W (2001) Roundtable on Chinese economic statistics: introduction. Chin Econ Rev 12:298-302

Roth E, Ackefors H, Asche F, Balnath C, Black E, Black K, Boghen A, Browdy C, Burbridge P, Castell JD, Chamberlain G, Dabrowski K, Davies I, Dosdat A, Eleftheriou A, Ervik A, Gordin H, Heinig CS, Hilge V, Karakassis I, Kuhlmann H, Landry T, von Lukowicz
M, McGlade J, Price A, Rheault RB, Rosenthal H, Saint-Paul U, Sandifer PA, Saroglia M, Silvert W, Steffens W, Soto D, Varadi L, Verreth J, Verdegem M, Waller U (2002) An intellectual injustice to aquaculture development: a response to the review article on "Effect of aquaculture on world fish supplies", Report of the ICES working group on environmental interactions of mariculture, F:04 REF ACME, Annex 4, pp 83-89

Ryan J (2005) Offshore aquaculture-Do we need it, and why is it taking so long? International Salmon Farmers Association (Ireland). Expert workshop on sustainable aquaculture, DG JRC European Commission, Institute for Prospective Technological Studies, 1718 January 2005, Seville, Spain

Stickney RR (1998) Joining forces with industry-open ocean aquaculture. Proceedings of the 3rd annual international conference, May 10-15, Corpus Christi, Texas. TAMU-SG-99-103, Corpus Christi, Texas Sea Grant College Program

Takayanagi K (1998) Water quality guidelines for aquaculture: an example in Japan. In: Howell WH, Keller BJ, Park PK, McVey JP, Takayanagi K, Uekita Y (eds) Nutrition and technical development of aquaculture. Proceedings of the 26th US-Japan aquaculture symposium, Durham/New Hampshire/USA September 16-18, 1997. UJNR technical report No. 26, Durham, University of New Hampshire Sea Grant Program, pp 247-254

Tiedemann A (2003) Windenergieparke im Meer - Perspektiven für den umweltverträglichen Einstieg in eine neue Großtechnologie. In: Lozán J, Rachor E, Reise K, Sündermann J, Westernhagen HV (eds) Warnsignale aus Nordsee \& Wattenmeer: Eine aktuelle Umweltbilanz. Wissenschaftliche Auswertungen, Hamburg, pp 142148

Turner R (2001) Offshore mariculture: site evaluation. In: Muir J, Basurco B (eds) Options méditerranéennes - Mediterranean offshore mariculture. Etudes et recherches, Serie B, Numéro 30, Zaragoza, CIHEAM, INO Reproducciones, pp 141-157

Voss D (2006) Parasitierungsgrad der Miesmuschel (Mytilus edulis) in Abhängigkeit zur Tiefenzonierung und Entfernung zur Küste. Thesis, University of Applied Sciences Bremerhaven, Germany

Walter U, Buck BH, Liebezeit G (2008) Larval occurrence and settlement in the German Bight - a trial to estimate potentials for $M y$ tilus edulis culture in offshore areas. Aquacult Int (in press)

Wirtz KW, Tol RSJ, Hooss KG (2003) Mythos "Offene See": Nutzungskonflikte im Meeresraum. In: Lozan L et al (eds) Warnsignale aus Nordsee \& Wattenmeer. Eine aktuelle Umweltbilanz. Wissenschaftliche Auswertungen, Hamburg, pp 157-160

Zielinski O, Assheuer J, Berg-Pollack A, Buck BH, Geisen M, Henkel R, Kassen D (2006) Assessment of mechanical loads and environmental conditions for extensive aquaculture constructions within offshore wind farms: first results from the AquaLast study site. Proceedings of DEWEK 2006: presented at the DEWEK 2006, 22-23 November 2006, Bremen, Germany, pp 1-4 